\title{
A review of particulate matter emissions and impacts on human health: A focus on Canadian agricultural and rural emission sources
}

\author{
Jennifer Spencer ${ }^{1}$ and Bill van Heyst ${ }^{1}$ \\ ${ }^{1}$ School of Engineering, University of Guelph, Guelph, ON N1G 2W1 Canada \\ E-mail: Billvan Heyst (bvanheyst@uoguelph.ca)
}

Submitted: 2018 July 19

Revision received: 2019 February 17

Accepted: 2019 April 18

Published online: 2019 April 18

\begin{abstract}
Particulate matter (PM) has been documented in an increasing number of research studies as having a known or suspected negative impact on human health. The World Health Organization (WHO) estimates that 3.1 million deaths were caused by ambient fine particulate matter $\left(\mathrm{PM}_{2.5}\right)$ in 2010. While many Canadian studies focus on health impacts from $\mathrm{PM}_{2.5}$, there is a gap with respect to rural sourced $\mathrm{PM}_{2.5}$ and health impacts in these areas. This paper reviews the impact $\mathrm{PM}_{2.5}$ has on Canadians' health, investigates where $\mathrm{PM}_{2.5}$ data is being gathered, and outlines the sources of $\mathrm{PM}_{2.5}$ reported. Secondary inorganic aerosols that are formed in and around animal production facilities due to the higher prevalence of ammonia gas is of particular interest. The conclusion drawn is that the reporting and gathering of rural sourced $\mathrm{PM}_{2.5}$ data is lacking, leading to a gap in the data used to determine the impacts on Canadian human health.
\end{abstract}

\section{RÉSUMÉ}

L'impact négatif connu ou potentiel sur la santé humaine de la matière particulaire (PM) a été documentée dans un nombre croissant d'études de recherche. L'Organisation mondiale de la Santé (OMS) estime que les fines particules ambiantes ( $\left.\mathrm{PM}_{2.5}\right)$ ont causé 3,1 millions de décès en 2010. Bien que de nombreuses études canadiennes portent sur les effets de $\mathrm{PM}_{2.5}$ sur la santé, il y a une lacune en ce qui concerne le $\mathrm{PM}_{2.5}$ d'origine rurale et les effets sur la santé dans ces régions. Le présent article examine l'impact des $\mathrm{PM}_{2.5}$ sur la santé des canadiens, analyse les endroits où les données sur le $\mathrm{PM}_{2.5}$ sont recueillies et décrit les sources du $\mathrm{PM}_{2.5}$ signalées. Les aérosols inorganiques secondaires qui se forment à l'intérieur et autour des installations de production animale en raison de la prévalence plus élevée de l'ammoniac à l'état gazeux est d'intérêt particulier. Nous concluons qu'il n'y a pas suffisamment de données sur le $\mathrm{PM}_{2.5}$ d'origine rurale, ce qui entraîne une lacune dans les données utilisées pour déterminer les effets sur la santé humaine au Canada.

\section{KEYWORDS}

Particulate matter, $\mathrm{PM}_{2.5}$, secondary inorganic aerosols, health, agriculture, ammonia.

\section{MOTS CLÉS}

La matière particulaire, $\mathrm{PM}_{2.5}$, Les aérosols inorganiques secondaires, santé, agriculture, ammoniac.

\section{CITATION}

Spencer, J., and B. van Heyst. 2018. A review of particulate matter emissions and impacts on human health: A focus on Canadian agricultural and rural emission sources. Canadian Biosystems Engineering/Le génie des biosystèmes au Canada 60: 6.9-6.21. https://doi.org/10.7451/CBE.2018.60.6.9 


\section{INTRODUCTION}

Particulate matter (PM) is one of several pollutants that make up the collective category of Criteria Air Contaminants in Canada (CACC) that have an adverse effect on human health, the environment, and economy (Government of Canada 2017). PM is categorized into two size fractions, coarse and fine. Coarse PM is referred to as $\mathrm{PM}_{10}$ due to it having an aerodynamic diameter of $10 \mu \mathrm{m}$ or smaller. Fine PM has an aerodynamic diameter of $2.5 \mu \mathrm{m}$ or smaller, is commonly referred to as $\mathrm{PM}_{2.5}$, and is responsible for a growing list of health problems afflicting humans (US EPA 2016a).

Particle size and type determines the location of deposition once inside the human respiratory tract. The four types of deposition include: interception, impaction, sedimentation, and diffusion. Larger particles $\left(>\mathrm{PM}_{10}\right)$ will often intercept or collide with the surfaces of the upper respiratory tract and eventually be expelled through physical means (coughing and/or sneezing). Particles smaller than $\mathrm{PM}_{10}$ can however travel to the lower regions of the respiratory tract and settle on the tissues of the bronchi and bronchioles or diffuse into the gas exchange areas of the alveoli (CCOHS 2018). When the smaller particles are deposited in the lower regions of the lungs, they are more difficult to expel and can remain in the system for extended periods of time resulting in the onset of problematic health conditions (Koenig 2000; CCOHS 2018).

The PM, both coarse and fine fractions, has been linked to a variety of health problems including: cardiopulmonary and cardiovascular diseases, diabetes, and various cancers (Brook et al. 2013; Crouse et al. 2012; WHO 2016a). In 2010, it was estimated by the World Health Organization (WHO) that 3.1 million deaths were caused by ambient outdoor $\mathrm{PM}_{2.5}$ (WHO 2013) with $91 \%$ of the global population exposed to concentrations that are above the recommended limit (annual mean of $10 \mu \mathrm{g} / \mathrm{m}^{3}$ ) (WHO 2016a). Further to this, in 2012 the WHO also reported that, although not specific to PM, 12.6 million deaths (in 2012 alone) were attributed to environmental pollution (PrüssUstüm et al. 2016). Lelieveld et al. (2015) approximated that premature deaths caused by $\mathrm{PM}_{2.5}$ was 3.3 million annually, while Silva et al. (2016) similarly found that anthropogenic $\mathrm{PM}_{2.5}$ was responsible for 2.23 million deaths annually. While there is variability around the exact global mortality estimate, the end result still suggests that $\mathrm{PM}_{2.5}$ is a significant contributing factor responsible for human mortality (Valavanidis et al. 2008). In response to the growing body of evidence linking PM to human mortality the WHO listed outdoor air pollution and particulate matter as cancer-causing agents, further solidifying the dangers associated with exposure to pollution and particulate matter (WHO 2013).

The WHO has set air quality guideline limits for 24-hour and annual PM averages in an attempt to reduce human exposure and with it, reducing the negative impacts on health. National and regional governing bodies are responsible for setting their own regulatory concentration limits. Regardless of the limits established by the WHO, $83 \%$ of monitoring sites located in Europe and Asia, recorded annual concentrations that surpass the WHO PM 10 limits (no comparison was given for $\mathrm{PM}_{2.5}$ ) (WHO 2013). In Canada, approximately $30 \%$ of its inhabitants are exposed to concentrations of $\mathrm{PM}_{2.5}$ that exceeded the national limit (Brook et al. 2014). However, what is less understood is contribution to this excess from the different $\mathrm{PM}_{2.5}$ sources and species and the associated health impacts to susceptible populations.

\section{Particulate matter standards}

Currently, regulatory bodies of individual countries set standards for ambient PM concentrations (this includes $\mathrm{PM}_{10}$ and $\mathrm{PM}_{2.5}$ ). These regulations are based on research and policy development, with the goal being to decrease emissions to reduce exposure and ultimately improve human health. However, even with such limits and regulations in place, global PM concentrations are still increasing (WHO 2016b). Table 1 below summarizes standards for $\mathrm{PM}_{10}$ and $\mathrm{PM}_{2.5}$ that are recommended by the WHO as well as current regulations in Canada. Current regulations in Europe and the United States are also listed for comparison.

In Canada, the Canadian Ambient Air Quality Standards (CAAQS) limits, which replaced the Canadian Wide Standards in 2013 (CCME 2014), are more stringent to promote human health. Included in the new standards are future target limits for $\mathrm{PM}_{2.5}$ (annual and 24-hour time scales) effective in 2020. In the United States, standards for total suspended particles (TSP), $\mathrm{PM}_{10}$, and $\mathrm{PM}_{2.5}$ are set by the United States Environmental Protection Agency's (US EPA) National Ambient Air Quality Standards (NAAQS). These standards take PM monitoring a step beyond what Canada and the WHO have dictated by incorporating limits with respect to PM size fractions: primary and secondary. Primary standards are established to protect against human health and sensitive populations, while secondary standards are established to protect environmental welfare in terms of visibility, crop protection, animals, and vegetation (not to be confused with the primary and secondary classifications based on formation mechanisms) (US EPA 2016b).

Based on Table 1, and focusing on the $\mathrm{PM}_{2.5}$ fraction, the WHO has developed the most stringent standards for both the 24-hour and annual mean concentrations of $\mathrm{PM}_{2.5}$. Canada, while currently matching the WHO annual standard, will have the most stringent standard starting in the year 2020. In Europe, the $\mathrm{PM}_{2.5}$ standard has an annual average of $25 \mu \mathrm{g} / \mathrm{m}^{3}$ which is significantly higher than the annual WHO guideline (European Commission 2017).

\section{Sources and formation of $\mathbf{P M}_{2.5}$}

Sources of $\mathrm{PM}_{2.5}$ are varied and include industrial practices, transportation, agriculture, household heating methods, and naturally occurring events (e.g. volcanic eruptions) to name a few. Across Canada, the most common sources of $\mathrm{PM}_{2.5}$ in order of greatest contribution as reported by Environment and Climate Change Canada (ECCC), are: open sources (occurring over large geographic rural areas and generated primarily from construction operations and agriculture), burning of firewood to heat homes, and other sources that include (in order): ore and mineral industries, transportation, manufacturing, miscellaneous, oil and gas industry, and energy uses (ECCC Air Pollutant Emissions 2017). In these reports it is not specified whether the $\mathrm{PM}_{2.5}$ emissions are primary or secondary. 
Table 1. Summary of selected air pollution standards for PM.

\begin{tabular}{|c|c|c|c|}
\hline Regulatory Body & $\mathrm{PM}_{10}$ & $\mathrm{PM}_{2.5}$ & Source \\
\hline \multirow[t]{2}{*}{ WHO } & Annual mean: $20 \mu \mathrm{g} / \mathrm{m}^{3}$ & Annual mean: $10 \mu \mathrm{g} / \mathrm{m}^{3}$ & \multirow[t]{2}{*}{ WHO 2006} \\
\hline & 24-hour mean: $50 \mu \mathrm{g} / \mathrm{m}^{3}$ & 24-hour mean: $25 \mu \mathrm{g} / \mathrm{m}^{3}$ & \\
\hline \multirow{4}{*}{$\begin{array}{l}\text { Canadian Ambient Air } \\
\text { Quality Standards } \\
\text { (CAAQS) - Replaced the } \\
\text { Canadian Wide Standards } \\
\text { in } 2013\end{array}$} & \multirow[t]{4}{*}{ N/A } & Annual mean (2015): $10 \mu \mathrm{g} / \mathrm{m}^{3}$ & \multirow{4}{*}{$\begin{array}{l}\text { Environment and Climate } \\
\text { Change Canada (CAAQS) } \\
2013\end{array}$} \\
\hline & & Annual mean (2020): $8.8 \mu \mathrm{g} / \mathrm{m}^{3}$ & \\
\hline & & 24-hour mean (2015): $28 \mu \mathrm{g} / \mathrm{m}^{3}$ & \\
\hline & & 24-hour mean (2020): $27 \mu \mathrm{g} / \mathrm{m}^{3}$ & \\
\hline \multirow[t]{2}{*}{ European Commission } & Annual mean: $40 \mu \mathrm{g} / \mathrm{m}^{3}$ & Annual mean: $25 \mu \mathrm{g} / \mathrm{m}^{3}$ & \multirow{2}{*}{$\begin{array}{l}\text { European Commission } \\
2017\end{array}$} \\
\hline & 24-hour mean: $50 \mu \mathrm{g} / \mathrm{m}^{3}$ & & \\
\hline \multirow{3}{*}{$\begin{array}{l}\text { US EPA - National Ambient } \\
\text { Air Quality Standards } \\
\text { (NAAQS) }\end{array}$} & Primary and secondary $-24-$ & Primary annual mean: $12.0 \mu \mathrm{g} / \mathrm{m}^{3}$ & \multirow[t]{3}{*}{ US EPA $2016 b$} \\
\hline & hour mean: $150 \mu \mathrm{g} / \mathrm{m}^{3}$ & Secondary annual mean: $15.0 \mu \mathrm{g} / \mathrm{m}^{3}$ & \\
\hline & & Primary and secondary 24-hour mean: $35 \mu \mathrm{g} / \mathrm{m}^{3}$ & \\
\hline
\end{tabular}

When a particle emission is classified as primary, it means that it has been emitted directly from the source and has been unchanged in its form. Examples of primary PM include: dust, animal dander, and soil particles. Secondary $\mathrm{PM}_{2.5}$ is formed when a reaction occurs between basic and acid precursor gases, such as ammonia and sulphur or nitrogen gases. This results in the two gases undergoing a neutralization via a gas-to-aerosol reaction, producing an aerosol particle in the $\mathrm{PM}_{2.5}$ size fraction. Behera and Sharma (2010) found that, in an urban environment, these reactions accounted for $30 \%$ of the mass of $\mathrm{PM}_{2.5}$ measured.

Ammonia is a basic gas involved in the gas-to-aerosol reaction for secondary $\mathrm{PM}_{2.5}$ formation and is often generated in its greatest quantity in animal production facilities (Behera and Sharma 2010; Roumeliotis et al. 2010; ECCC 2016). The greatest sources of ammonia in Canada are from agricultural operations that include both animal and crop production (use of synthetic fertilizers) and represent 94\% of all emissions (APEI 2019). In Canada ammonia emissions have increased by $24 \%$ since 1990 (ECCC 2018) due to agricultural practices that can contribute to the secondary inorganic aerosol (SIA) $\mathrm{PM}_{2.5}$ burden.

Agriculture and Agri-Food Canada (AAFC) has been measuring and analyzing particulate matter emissions data from cropping activities nationally since 1993. This endeavor is part of the environmental indicators reporting program (known as Agri-Environmental Indicators (AEI)) that includes ammonia emissions, soil erosion, and soil cover data. The analysis of $\mathrm{PM}_{2.5}$ emissions (total mass) from cropping operations has shown a declining trend that is attributed to the adoption of less intensive tilling practices which reduces the amount of particulate matter becoming air borne, and reduced summerfallow. Since 1993, $\mathrm{PM}_{2.5}$ decreased from 522 kilotonnes/year to 276 kilotonnes/year in 2011, a reduction of 46\% (AAFC PMI 2016).

The design and function of modern animal production facilities lends itself to increased emissions of secondary $\mathrm{PM}_{2.5}$. Enclosed animal production facilities, common in Canadian agriculture, creates an environment suitable for the generation and accumulation of ammonia and acid gases such as sulphuric acid $\left(\mathrm{H}_{2} \mathrm{SO}_{4}\right)$, nitric acid $\left(\mathrm{HNO}_{3}\right)$, and hydrochloric acid (HCl) (Behera and Sharma 2010). Ammonia is formed during the microbial breakdown of nitrogen-rich animal excrement (Behera and Sharma 2010; Roumeliotis et al. 2010). When acid gases and ammonia are present, a neutralization reaction occurs forming a secondary inorganic aerosol (SIA), contributing to the total $\mathrm{PM}_{2.5}$ burden. The formed SIAs include: ammonium sulphate $\left(\left(\mathrm{NH}_{4}\right)_{2} \mathrm{SO}_{4}\right)$, ammonium bisulfate $\left(\mathrm{NH}_{4} \mathrm{HSO}_{4}\right)$, ammonium nitrate $\left(\mathrm{NH}_{4} \mathrm{NO}_{3}\right)$, and ammonium chloride $\left(\mathrm{NH}_{4} \mathrm{Cl}\right)($ Behera and Sharma 2010$)$. In poultry production, it is known that the formation mechanisms of these reactions are dependent on environmental conditions within the animal housing unit, the environmental conditions outside the housing unit including seasonal variability, and the animal's stage of growth (Roumeliotis et al. 2010). While government bodies have yet to regulate emissions from animal production facilities in Canada, understanding the extent of $\mathrm{PM}_{2.5}$ contribution from agriculture can help to strengthen the overall understanding of this pollutant's impact on human health. Currently, secondary $\mathrm{PM}_{2.5}$ is not directly estimated by Canadian governing bodies and therefore has not been reported in pollution summary reports.

Particulate matter and health - The Canadian context

The PM studies, whether they are focused on human health effects, source-receptor relationships, or formation mechanisms, utilize data gathered primarily from urban areas (WHO 2016b). Studies focused on human health impacts use urban-based PM data correlated with population health data that is also obtained from urbandwelling participants. In terms of the Canadian context, the majority of the population (81\%) is classified as living in an urban dwelling (Statistics Canada 2011) while the remaining population is located in smaller rural/remote areas of the country.

Research related to health impacts associated with particulate matter exposure is considerable. Health effects caused by the exposure to PM primarily affect the function of the lungs and the heart. Several conditions such as respiratory diseases, cardiovascular and cardiopulmonary conditions, diabetes, and cancers are associated with mortality and morbidity caused by $\mathrm{PM}_{2.5}$ (Pope III et al. 
2004; Pope III and Dockery 2006). Table 2 presents a summary of study's findings pertaining to health effects associated with long and short-term exposure to fine particulate matter in Canada since the year 2000.

The studies highlighted in Table 2 demonstrates that increased exposure to $\mathrm{PM}_{2.5}$ within Canada correlates to an increase the risk of mortality. It also demonstrates that the majority of studies focus on populations and pollution measurements from urban locations. What was not included in Table 2 are studies that highlight the health impacts of PM exposure on children. For example, Tetreault et al. (2016) looked into the effects of exposure to PM and the onset of childhood asthma in Montreal, Quebec, Canada and found that the onset of asthma in children was associated with exposure to $\mathrm{PM}_{2.5}, \mathrm{NO}_{2}$ and $\mathrm{O}_{3}$. Lavigne et al. (2017) looked at ambient air pollution and its effects on adverse birth outcomes in Ontario and determined that exposure to ambient $\mathrm{PM}_{2.5}$ and $\mathrm{NO}_{2}$ during pregnancy was associated with the onset of astrocytoma (a form of brain cancer) in children. Further, studies focused on pregnant women and the health of their newborns include Erickson et al. (2016) and Brauer et al. (2008) who both determined that expecting mothers who were exposed to $\mathrm{PM}_{2.5}$, in urban areas, gave birth to children with lower birth weights. These studies, like the majority of those outlined in Table 2, were based on data gathered from urban dwelling populations in Canada and urban $\mathrm{PM}_{2.5}$ data. What is less understood are the $\mathrm{PM}_{2.5}$ emissions from rural areas and the impacts on the health of Canadian residents living in those areas.

\section{Canadian agriculture and rural particulate matter}

Canada's large landmass and low overall population density (3.9 persons $/ \mathrm{km}^{2}$ in 2016 (Statistic Canada 2018)) with several large urban centers (Statistics Canada 2017b) results in there being a large expanse of rural agricultural and/or natural landscapes. This combination of landscape extremes presents a unique combination of factors when discussing PM in the Canadian context. In Canada, $\mathrm{PM}_{2.5}$ emissions are measured from a network of monitoring stations that are then analyzed and reported by ECCC. Data tables made available by ECCC from 2013 show that there was a total of 385 monitoring stations situated throughout the country gathering hourly data. An assessment of the gathered data from this network has been summarized below in Table 3.

Table 3 above outlines the available $\mathrm{PM}_{2.5}$ data from monitoring stations across Canada for 2013. Based on the summary provided, the majority of data is collected in urban areas, primarily within British Columbia, Ontario, and Quebec. Of the $\mathrm{PM}_{2.5}$ data gathered from monitoring stations in rural areas, the averages are similar to urban areas, but from significantly fewer stations. There was no rural data reported from two of the three prairie provinces (Manitoba and Saskatchewan) that represent a substantial area of Canada's agricultural land mass. It should be noted that the three territories do not have land mass suitable for standard agricultural practices and are therefore not a concern in this context. Of the 31 agricultural stations, only 13 reported data for either peak or average $\mathrm{PM}_{2.5}$ concentrations in 2013, while only 33 rural area stations in total had data to report (ECCC 2014). Due to the majority of ambient monitoring stations being located in urban areas, comparatively fewer PM studies focusing on emissions from Canada's rural areas have occurred as outlined earlier in Table 2.

Agricultural land in Canada accounts for 158.7 million acres $(7.1 \%$ of the total landmass) and is operated by approximately $272 \times 10^{3}$ farmers (Statistics Canada 2017a; Statistics Canada 2017b). Agricultural production in Canada accounted for $6.7 \%$ of the total national Gross Domestic Product in 2016, a growth of 11\% since 2012 (AAFC 2017) and is the $5^{\text {th }}$ largest global exporter of agricultural products (AAFC 2018). The farmers, their families, agricultural operations, and the rural landscape is often overlooked when it comes to studying PM, specifically monitoring and quantifying the concentrations of $\mathrm{PM}_{2.5}$ and linking it to potential health impacts. With a predominate agricultural sector in Canada, in terms of production and landmass, what impact do the subsequent $\mathrm{PM}_{2.5}$ emissions of have on human health?

Agricultural practices result in the emission of primary PM (all size fractions) from land preparation, nutrient and pesticide applications, crop harvesting, animal husbandry operations, and fuel use. In the most recent annual report from ECCC's Air Pollutant Emission Inventory (APEI) Report, it was estimated that $1.7 \times 10^{6}$ tonnes of $\mathrm{PM}_{2.5}$ were emitted in Canada during 2017 with agriculture accounting for $3.80 \times 10^{5}$ tonnes, or $22 \%$ of the total $\mathrm{PM}_{2.5}$ emissions (APEI 2019). Ammonia emissions totaled $4.80 \times 10^{5}$ tonnes with agriculture contributing $4.50 \times 10^{5}$ tonnes or $94 \%$ of emissions (APEI 2019). Overall, it was noted that $\mathrm{PM}_{2.5}$ and ammonia have either remained stable or fluctuated slightly since 2012 (APEI 2019). This summary does not directly identify if the $\mathrm{PM}_{2.5}$ emissions were primary or secondary. Secondary inorganic aerosol formation attributed to ammonia (agriculture) was also not identified. Table 4 below gives a summary of PM emission quantities with respect to their size fraction, and ammonia emission quantities from Canada as of 2017 based on APEI (2019) reported data.

In addition to the emission from agricultural and rural sources as outlined by APEI (2019), emissions of PM and ammonia from 'other' rurally located sources were included to demonstrate the magnitude of emissions possibly occurring outside urban centers in Canada. Off-road diesel and gasoline vehicles, which can include agricultural equipment, contribute to $\mathrm{PM}_{2.5}$ emissions in the form of dust and fossil fuel combustion however, this contribution of $\mathrm{PM}_{2.5}$ emission quantity is not included as part of the agriculture sector contribution (APEI 2019). These vehicles play a significant role in agricultural operations with respect to the transportation of products to and from the farm, and on farm transportation. When considering the full impact of agriculture and rural sources of $\mathrm{PM}_{2.5}$, the contributions of the "other" sources listed in Table 4 should be included in the conversation. When all sources of PM and ammonia in both sectors are added together, the total 
Table 2. Summary of Canadian studies pertaining to particulate matter and health impacts (presented in reverse chronological order for long- and short-term exposure; R - Rural, U - Urban, AL - All Land).

\begin{tabular}{|c|c|c|c|c|}
\hline $\begin{array}{l}\text { Study } \\
\text { Reference }\end{array}$ & $\begin{array}{l}\text { Study } \\
\text { Location }\end{array}$ & Study Participants & Pollutant of Interest & Health Effects/Impacts \\
\hline \multicolumn{5}{|c|}{ Long-Term Exposure: } \\
\hline Chen et al 2017 & $\begin{array}{l}\text { Ontario, } \\
\text { Canada } \\
(\mathrm{AL})\end{array}$ & $\begin{array}{l}\text { Residents aged } 55-85 \\
\text { by April } 1,2001 \text { with } \\
\text { no diagnosis of } \\
\text { dementia ( } 2.1 \text { million } \\
\text { persons) who were } \\
\text { followed until March } \\
31,2013\end{array}$ & $\begin{array}{l}\mathrm{PM}_{2.5} \text { exposure }- \text { satellite } \\
\text { and global atmospheric } \\
\text { chemistry transport } \\
\text { model data for all of } \\
\text { North America }\end{array}$ & $\begin{array}{l}\text { The } 257,816 \text { cases of dementia diagnosed } \\
\text { between } 2001 \text { and } 2013 \text { were positively linked } \\
\text { to an increase in dementia due to exposure to } \\
\mathrm{PM}_{2.5} \text { (average concentration of } 10.4 \mu \mathrm{g} / \mathrm{m}^{3} \text { ). }\end{array}$ \\
\hline $\begin{array}{l}\text { Pinault et al. } \\
2016\end{array}$ & $\begin{array}{l}\text { Canada } \\
(\mathrm{AL})\end{array}$ & $\begin{array}{l}\text { Respondents to the } \\
\text { Canadian Community } \\
\text { Health Survey: } \\
299,500 \text { individuals } \\
\text { followed from } 2000 \\
\text { to } 2008\end{array}$ & $\begin{array}{l}\text { Low concentration } \\
\text { ambient } \mathrm{PM}_{2.5}(\text { mean } 6.3 \\
\left.\mu \mathrm{g} / \mathrm{m}^{3}\right) \text { - satellite data }\end{array}$ & $\begin{array}{l}26,300 \text { non-accidental deaths ( } 32.5 \% \text { due to } \\
\text { circulatory disease, } 9.1 \% \text { due to respiratory } \\
\text { disease). An increase of } 10 \mu \mathrm{g} / \mathrm{m}^{3} \text { in } \mathrm{PM}_{2.5} \\
\text { was found to be associated with an increase in } \\
\text { non-accidental, circulatory, and respiratory } \\
\text { mortality. }\end{array}$ \\
\hline $\begin{array}{l}\text { Stieb et al. } \\
2015\end{array}$ & $\begin{array}{l}\text { Canada } \\
\text { (AL) }\end{array}$ & $\begin{array}{l}\text { Census Data for } \\
\text { adults of } 25 \text { years of } \\
\text { age from } 2000 \text { to } \\
2011\end{array}$ & $\begin{array}{l}\text { Ambient } \mathrm{PM}_{2.5} \text { from } \\
2000 \text { to } 2011-\text { satellite } \\
\text { data }\end{array}$ & $\begin{array}{l}\text { Determined a decrease in } \mathrm{PM}_{2.5} \text { by } 25 \% \text { during } \\
\text { the years studied resulted in an increase in life } \\
\text { expectancy by } 0.10 \text { years. An increase in } \\
\mathrm{PM}_{2.5} \text {, up to } 3.5 \mu \mathrm{g} / \mathrm{m}^{3} \text {, was observed over the } \\
\text { prairies. }\end{array}$ \\
\hline To et al. $2015 \mathrm{a}$ & $\begin{array}{l}\text { Ontario } \\
\text { (AL) }\end{array}$ & $\begin{array}{l}\text { Women who enrolled } \\
\text { in the Canadian } \\
\text { National Breast } \\
\text { Screening Study from } \\
1980 \text { to } 1985 \text { ( } 29,549 \\
\text { women) and linked to } \\
\text { administrative data to } \\
\text { determine the } \\
\text { prevalence of chronic } \\
\text { disease between } 1992 \\
\text { and } 2013\end{array}$ & $\begin{array}{l}\text { Ambient } \mathrm{PM}_{2.5} \text { from } \\
1998 \text { to } 2006 \text { - satellite } \\
\text { estimates of surface } \\
\text { concentrations (no mean } \\
\text { was given) }\end{array}$ & $\begin{array}{l}\text { Congestive heart failure, diabetes, ischemic } \\
\text { heart disease and stroke were all associated } \\
\text { with a greater than } 20 \% \text { prevalence rate ratio } \\
\text { based on a } 10 \mu \mathrm{g} / \mathrm{m}^{3} \text { increase in } \mathrm{PM}_{2.5}\end{array}$ \\
\hline $\begin{array}{l}\text { Villeneuve et } \\
\text { al. } 2015\end{array}$ & $\begin{array}{l}\text { Canada } \\
\text { (AL) }\end{array}$ & $\begin{array}{l}89,248 \text { women } \\
\text { enrolled in the } \\
\text { Canadian National } \\
\text { Breast Screening } \\
\text { Study between } 1980 \\
\text { and } 1985\end{array}$ & $\begin{array}{l}\text { Ambient } \mathrm{PM}_{2.5} \text { from } \\
1998 \text { to } 2006 \text { - satellite } \\
\text { observations - average of } \\
9.1 \mu \mathrm{g} / \mathrm{m}^{3}\end{array}$ & $\begin{array}{l}\text { A } 10 \mu \mathrm{g} / \mathrm{m}^{3} \text { increase in } \mathrm{PM}_{2.5} \text { exposure was } \\
\text { associated with elevated risk of non-accidental } \\
\text { and ischemic heart disease mortality. }\end{array}$ \\
\hline $\begin{array}{l}\text { Chen et al. } \\
2014\end{array}$ & $\begin{array}{l}\text { Ontario } \\
(\mathrm{AL})\end{array}$ & $\begin{array}{l}35,303 \text { non- } \\
\text { hypertensive adults } \\
\text { who responded to a } \\
\text { health survey }-65 \% \\
\text { in urban areas }\end{array}$ & $\begin{array}{l}\text { Ambient } \mathrm{PM}_{2.5} \text { from } \\
2001 \text { to } 2006 \text { - satellite } \\
\text { average at participants } \\
\text { residences } 10.7 \mu \mathrm{g} / \mathrm{m}^{3}\end{array}$ & $\begin{array}{l}\text { For every } 10 \mu \mathrm{g} / \mathrm{m}^{3} \text { increase in } \mathrm{PM}_{2.5} \text {, the } \\
\text { hazard ratio for incident hypertension is } 1.13 \text {, } \\
\text { therefore supporting the claim that } \mathrm{PM}_{2.5} \text { is } \\
\text { correlated with hypertension. }\end{array}$ \\
\hline $\begin{array}{l}\text { Brook et al. } \\
2013\end{array}$ & $\begin{array}{l}\text { Canada } \\
(\mathrm{AL})\end{array}$ & $\begin{array}{l}\text { Adults over } 25 \text { years } \\
\text { of age who were } \\
\text { selected to complete } \\
\text { the } 1991 \text { long form } \\
\text { Census: } \\
2.1 \text { million adults }\end{array}$ & $\begin{array}{l}\text { Ambient } \mathrm{PM}_{2.5} \text { from } \\
2001 \text { to } 2006-\text { satellite } \\
\text { data average } 8.7 \mu \mathrm{g} / \mathrm{m}^{3}\end{array}$ & $\begin{array}{l}\text { Diabetes mortality was found to be positively } \\
\text { associated with } \mathrm{PM}_{2.5} \text { exposure. When } \\
\text { adjusted for a } 10 \mu \mathrm{g} / \mathrm{m}^{3} \text { increase in } \mathrm{PM}_{2.5} \text {, there } \\
\text { was an increased risk for mortality associated } \\
\text { with diabetes. }\end{array}$ \\
\hline $\begin{array}{l}\text { Chen et al. } \\
2013\end{array}$ & $\begin{array}{l}\text { Ontario } \\
(\mathrm{AL})\end{array}$ & $\begin{array}{l}62,012 \text { non-diabetics } \\
\text { that were followed } \\
\text { from } 1996 \text { to } 2005- \\
66 \% \text { in urban areas }\end{array}$ & $\begin{array}{l}\text { Ambient } \mathrm{PM}_{2.5} \text { from } \\
2001 \text { to } 2006-\text { satellite } \\
\text { data average } 10.6 \mu \mathrm{g} / \mathrm{m}^{3}\end{array}$ & $\begin{array}{l}\text { Long term exposure to } \mathrm{PM}_{2.5} \text { may contribute to } \\
\text { the onset of diabetes in adults. }\end{array}$ \\
\hline $\begin{array}{l}\text { Crouse et al. } \\
2012\end{array}$ & $\begin{array}{l}\text { Canada }(\mathrm{R} \\
\text { and } \mathrm{U})\end{array}$ & $\begin{array}{l}\text { People eligible for the } \\
\text { Canadian Census } \\
\text { Mortality Study: } \\
2.145 \text { million people } \\
\text { (Wilkins et al. 2008) } \\
-73 \% \text { in urban areas }\end{array}$ & $\begin{array}{l}\text { Ambient } \mathrm{PM}_{2.5} \text { from } \\
1987 \text { to } 2001 \text { - ground } \\
\text { stations average } 8.7 \\
\mu \mathrm{g} / \mathrm{m}^{3} \\
\mathrm{PM}_{2.5}-\mathrm{rural} / \text { farm }=6.5 \\
\mu \mathrm{g} / \mathrm{m}^{3} \\
\mathrm{PM} 2.5-\text { urban }=\text { range } 7.6 \\
\mu \mathrm{g} / \mathrm{m}^{3} \text { to } 11.1 \mu \mathrm{g} / \mathrm{m}^{3}\end{array}$ & $\begin{array}{l}\text { Strongest association was found to be with } \\
\text { ischemic heart disease, having a Hazard Ratio } \\
\text { (a comparison of events between two groups) } \\
\text { of } 1.31 \text {. Positive hazard ratios were also found } \\
\text { for non-accidental, cardiovascular, and } \\
\text { circulatory causes of death with a } 10 \mu \mathrm{g} / \mathrm{m}^{3} \\
\text { increase in } \mathrm{PM}_{2.5} \text {. }\end{array}$ \\
\hline
\end{tabular}




\begin{tabular}{|c|c|c|c|c|}
\hline $\begin{array}{l}\text { Study } \\
\text { Reference }\end{array}$ & $\begin{array}{l}\text { Study } \\
\text { Location }\end{array}$ & Study Participants & Pollutant of Interest & Health Effects/Impacts \\
\hline Gan et al. 2011 & $\begin{array}{l}\text { Vancouver, } \\
\text { British } \\
\text { Columbia } \\
\text { (U) }\end{array}$ & $\begin{array}{l}\text { Individuals aged } 45 \\
\text { to } 85 \text { years in } \\
\text { metropolitan } \\
\text { Vancouver: } 445,868 \\
\text { people }\end{array}$ & $\begin{array}{l}\text { Ambient } \mathrm{PM}_{2.5} \text { from } \\
1994 \text { to } 1999-\text { traffic and } \\
\text { black carbon emissions } \\
\mathrm{PM}_{2.5} \text { average } 4.08 \mu \mathrm{g} / \mathrm{m}^{3}\end{array}$ & $\begin{array}{l}\text { Risk of coronary heart disease mortality } \\
\text { increased by } 6 \% \text { when exposed to black } \\
\text { carbon, but not } \mathrm{PM}_{2.5}\end{array}$ \\
\hline $\begin{array}{l}\text { Elliot and } \\
\text { Copes } 2011\end{array}$ & $\begin{array}{l}\text { Rural } \\
\text { Interior and } \\
\text { Northern } \\
\text { British } \\
\text { Columbia } \\
\text { (R) }\end{array}$ & $\begin{array}{l}\text { Adults } 30 \text { years of } \\
\text { age and older }\end{array}$ & $\begin{array}{l}\text { Ambient } \mathrm{PM}_{2.5} \text { from } \\
2005 \text { to } 2009-\text { measured } \\
\text { from near-by urban } \\
\text { stations, average range } \\
3.1 \mu \mathrm{g} / \mathrm{m}^{3} \text { to } 7.4 \mu \mathrm{g} / \mathrm{m}^{3} \\
\text { annual mean } 5 \text {-year } \\
\text { period }\end{array}$ & $\begin{array}{l}\text { Anthropogenic } \mathrm{PM}_{2.5} \text { was responsible for } 74 \\
\text { deaths per year for all-cause mortality. }\end{array}$ \\
\hline $\begin{array}{l}\text { Chen et al. } \\
2004\end{array}$ & $\begin{array}{l}\text { Vancouver, } \\
\text { British } \\
\text { Columbia } \\
\text { (U) }\end{array}$ & $\begin{array}{l}\text { Elderly population } \\
(65 \text { years of age and } \\
\text { older) between } 1995 \\
\text { and } 1999\end{array}$ & $\begin{array}{l}\text { Ambient PM (all size } \\
\text { fractions) from } 1995 \text { to } \\
1999 \text { - ground level } \\
\text { monitors average } \mathrm{PM}_{2.5} \\
7.7 \mu \mathrm{g} / \mathrm{m}^{3}\end{array}$ & $\begin{array}{l}\text { Low-concentrations of PM }\left(\mathrm{PM}_{10}=13.3\right. \\
\left.\mu \mathrm{g} / \mathrm{m}^{3}, \mathrm{PM}_{2.5}=7.7 \mu \mathrm{g} / \mathrm{m}^{3}\right) \text { was found to be } \\
\text { associated with COPD hospitalizations }\end{array}$ \\
\hline \multicolumn{5}{|c|}{ Short-Term Exposure: } \\
\hline To et al. $2015 b$ & $\begin{array}{l}\text { Ontario } \\
\text { (AL) }\end{array}$ & $\begin{array}{l}\text { Individuals (location } \\
\text { not specified) who } \\
\text { received either } \\
\text { primary or secondary } \\
\text { medical attention } \\
\text { between } 2003 \text { and } \\
2010 \text { and resided in } \\
\text { Ontario and suffered } \\
\text { from: asthma, COPD, } \\
\text { diabetes, } \\
\text { hypertension, angina, } \\
\text { acute myocardial } \\
\text { infarction, ischemic } \\
\text { heart disease, } \\
\text { congestive heart } \\
\text { failure, stroke, lung } \\
\text { cancer, and non-lung } \\
\text { cancers were included }\end{array}$ & $\begin{array}{l}\text { AQHI scale - including } \\
\mathrm{PM}_{2.5}, \mathrm{NO}_{2} \text {, and } \mathrm{O}_{3}\end{array}$ & $\begin{array}{l}\text { Incremental unit increase of the AQHI scale } \\
\text { (equivalent increases: } \mathrm{NO}_{2}=10 \mathrm{ppb}, \mathrm{PM}_{2.5}= \\
10 \mu \mathrm{g} / \mathrm{m}^{3} \text {, and } \mathrm{O}_{3}=10 \mathrm{ppb} \text { ) resulted in } \\
\text { increased outpatient visits by } 1 \% \text { to } 5 \% \text { which } \\
\text { equates to } 15,000 \text { patients. These increased } \\
\text { visits continued for } 2 \text {-days after the AQHI } \\
\text { scale increased. }\end{array}$ \\
\hline $\begin{array}{l}\text { Szyszkowicz } \\
\text { and Kousha } \\
2014\end{array}$ & $\begin{array}{l}\text { Windsor, } \\
\text { Ontario (U) }\end{array}$ & $\begin{array}{l}\text { Emergency room } \\
\text { visits between } 2004 \\
\text { to } 2010 \text { associated } \\
\text { with asthma - } 6,697 \\
\text { patients in total }\end{array}$ & $\begin{array}{l}\text { Ambient air pollution as } \\
\text { determined by the AQHI } \\
\left(\mathrm{PM}_{2.5}, \mathrm{NO}_{2} \text {, and } \mathrm{O}_{3}\right)\end{array}$ & $\begin{array}{l}\text { Exposure to ambient air pollution were } \\
\text { positively correlated with ER visits for asthma. } \\
\text { Younger people were affected on the same day } \\
\text { as air quality deteriorated, while older people } \\
\text { had a lagged response to the poor air quality. }\end{array}$ \\
\hline $\begin{array}{l}\text { Goldberg et al. } \\
2006\end{array}$ & $\begin{array}{l}\text { Montreal, } \\
\text { Quebec (U) }\end{array}$ & $\begin{array}{l}\text { Deaths of Montreal } \\
\text { residents who were } \\
\text { diagnosed with } \\
\text { diabetes and also had } \\
\text { cardiorespiratory } \\
\text { conditions between } \\
1984 \text { to } 1993 ; 2,947 \\
\text { deaths occurred in } \\
\text { persons over } 65 \text { years } \\
\text { of age. }\end{array}$ & $\begin{array}{l}\text { Daily concentrations of } \\
\mathrm{PM}_{2.5} \text { and } \mathrm{PM}_{10} \text { and } \\
\text { gaseous pollutants }\left(\mathrm{SO}_{2},\right. \\
\left.\mathrm{NO}_{2}, \mathrm{CO}, \mathrm{O}_{3}\right) \text { were } \\
\text { linked back to day of } \\
\text { death- ground monitors. }\end{array}$ & $\begin{array}{l}\text { Individuals with diabetes and cardiovascular } \\
\text { disease have an increased risk for death when } \\
\text { exposed to increased air pollution } \\
\text { concentrations that include } \mathrm{PM}_{2.5} \text {. }\end{array}$ \\
\hline $\begin{array}{l}\text { Jerrett et al. } \\
2004\end{array}$ & $\begin{array}{l}\text { Hamilton, } \\
\text { Ontario (U) }\end{array}$ & $\begin{array}{l}\text { Mortality data from } \\
1985 \text { to } 1994 \text { within } \\
\text { the city limits }\end{array}$ & $\begin{array}{l}\mathrm{PM} \text { as measured by the } \\
\text { coefficient of haze }\left(\mathrm{SO}_{2}\right. \\
\text { also included) - ground } \\
\text { monitors within } \\
\text { Hamilton city limits }\end{array}$ & $\begin{array}{l}\text { Mortality increases were associated with air } \\
\text { pollution exposure city wide, especially areas } \\
\text { with lower socioeconomic status }\end{array}$ \\
\hline $\begin{array}{l}\text { Villeneuve et } \\
\text { al. } 2003\end{array}$ & $\begin{array}{l}\text { Vancouver, } \\
\text { Canada (U) }\end{array}$ & $\begin{array}{l}550,000 \text { individuals } \\
\text { between } 1986 \text { and } \\
1999 \text { and mortality }\end{array}$ & $\begin{array}{l}\mathrm{PM}_{10} \text { and } \mathrm{PM}_{2.5} \text { and } \\
\text { gaseous pollutants }\left(\mathrm{O}_{3} \text {, }\right. \\
\left.\mathrm{CO}, \mathrm{SO}_{2} \text {, and } \mathrm{NO}_{2}\right)- \\
\text { daily continuous ground } \\
\text { sampling }\end{array}$ & $\begin{array}{l}\mathrm{PM}_{10} \text { was associated with increased } \\
\text { cardiovascular mortality, but } \mathrm{PM}_{2.5} \text { was not } \\
\text { found to be correlated as a predictor of } \\
\text { mortality }\end{array}$ \\
\hline
\end{tabular}


Table 3. Summary of Canadian monitoring station PM2.5 concentrations - 2013 (ECCC 2014).

\begin{tabular}{|c|c|c|c|c|c|c|}
\hline Region & Land Type & $\begin{array}{l}\text { Peak PM } \\
\left(\mu \mathrm{g} / \mathrm{m}^{3}\right)\end{array}$ & $\begin{array}{l}\text { Average } \\
\mathrm{PM}_{2.5}\end{array}$ & $\begin{array}{l}\text { No. } \\
\text { Stations } \\
\text { (total) }\end{array}$ & $\begin{array}{l}\text { No. } \\
\text { Stations } \\
\text { with } \\
\text { Recorded } \\
\text { Data } \\
\end{array}$ & $\begin{array}{l}\text { SD for } \\
\text { average } \\
\mathrm{PM}_{2.5} \\
\left(\mu \mathrm{g} / \mathrm{m}^{3}\right)\end{array}$ \\
\hline \multirow[t]{3}{*}{ Summary } & Rural agricultural areas & 18.34 & 6.68 & 31 & 13 & 2.05 \\
\hline & Rural but not agricultural areas & 15.36 & 5.26 & 61 & 20 & 1.18 \\
\hline & Urban areas & 17.78 & 6.93 & 293 & 133 & 1.90 \\
\hline \multirow[t]{3}{*}{ Alberta } & Rural agricultural areas & 14.48 & 5.18 & 12 & 5 & 2.16 \\
\hline & Rural but not agricultural areas & 13.80 & 4.98 & 11 & 3 & 0.98 \\
\hline & Urban areas & 22.29 & 7.66 & 34 & 20 & 1.83 \\
\hline \multirow[t]{3}{*}{ British Columbia } & Rural agricultural areas & $\mathrm{N} / \mathrm{A}$ & & 1 & 0 & \\
\hline & Rural but not agricultural areas & 11.60 & 5.20 & 6 & 1 & $\mathrm{~N} / \mathrm{A}$ \\
\hline & Urban areas & 16.11 & 6.04 & 102 & 33 & 1.91 \\
\hline \multirow[t]{3}{*}{ Manitoba } & Rural agricultural areas & N/A & & 0 & 0 & \\
\hline & Rural but not agricultural areas & N/A & & 0 & 0 & \\
\hline & Urban areas & 21.84 & 5.75 & 5 & 5 & 0.94 \\
\hline \multirow[t]{3}{*}{ New Brunswick } & Rural agricultural areas & N/A & & 0 & 0 & \\
\hline & Rural but not agricultural areas & 17.80 & 7.00 & 9 & 1 & N/A \\
\hline & Urban areas & 18.81 & 6.49 & 9 & 7 & 1.45 \\
\hline \multirow{3}{*}{$\begin{array}{l}\text { Newfoundland and } \\
\text { Labrador }\end{array}$} & Rural agricultural areas & N/A & & 0 & 0 & \\
\hline & Rural but not agricultural areas & N/A & & 0 & 0 & \\
\hline & Urban areas & 15.75 & 5.58 & 8 & 4 & 0.71 \\
\hline \multirow[t]{3}{*}{ Northwest Territories } & Rural agricultural areas & $\mathrm{N} / \mathrm{A}$ & & 0 & 0 & \\
\hline & Rural but not agricultural areas & N/A & & 1 & 0 & \\
\hline & Urban areas & 22.30 & 4.50 & 4 & 2 & 2.69 \\
\hline \multirow[t]{3}{*}{ Nova Scotia } & Rural agricultural areas & N/A & & 1 & 0 & \\
\hline & Rural but not agricultural areas & 16.10 & 5.10 & 4 & 1 & $\mathrm{~N} / \mathrm{A}$ \\
\hline & Urban areas & 16.83 & 6.45 & 6 & 3 & 0.21 \\
\hline \multirow[t]{3}{*}{ Nunavut } & Rural agricultural areas & N/A & & 0 & 0 & \\
\hline & Rural but not agricultural areas & N/A & & 1 & 0 & \\
\hline & Urban areas & N/A & & 0 & 0 & \\
\hline \multirow[t]{3}{*}{ Ontario } & Rural agricultural areas & 19.30 & 7.90 & 4 & 1 & N/A \\
\hline & Rural but not agricultural areas & 17.90 & 6.23 & 13 & 3 & 1.27 \\
\hline & Urban areas & 18.09 & 7.15 & 69 & 35 & 1.19 \\
\hline \multirow[t]{3}{*}{ Prince Edward Island } & Rural agricultural areas & N/A & & 0 & 0 & \\
\hline & Rural but not agricultural areas & N/A & & 0 & 0 & \\
\hline & Urban areas & N/A & & 0 & 0 & \\
\hline \multirow[t]{3}{*}{ Quebec } & Rural agricultural areas & 20.96 & 7.59 & 12 & 7 & 1.49 \\
\hline & Rural but not agricultural areas & 14.95 & 4.81 & 12 & 11 & 1.20 \\
\hline & Urban areas & 25.06 & 9.98 & 43 & 20 & 1.67 \\
\hline \multirow[t]{3}{*}{ Saskatchewan } & Rural agricultural areas & N/A & & 1 & 0 & \\
\hline & Rural but not agricultural areas & N/A & & 0 & 0 & \\
\hline & Urban areas & 15.63 & 6.33 & 4 & 3 & 0.13 \\
\hline \multirow[t]{3}{*}{ Yukon Territories } & Rural agricultural areas & N/A & & 0 & 0 & \\
\hline & Rural but not agricultural areas & N/A & & 0 & 0 & \\
\hline & Urban areas & 19.90 & 6.20 & 1 & 1 & $\mathrm{~N} / \mathrm{A}$ \\
\hline
\end{tabular}


Table 4. APEI agricultural and rural emissions data (APEI 2019).

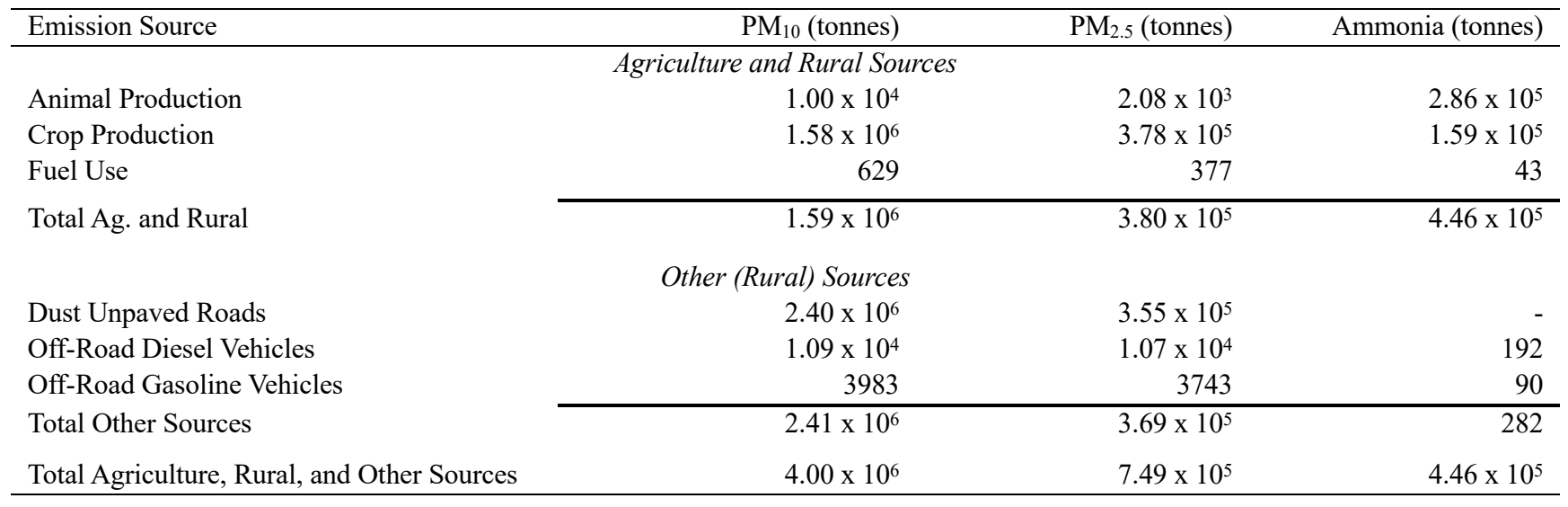

amounts of the three pollutants combine to demonstrate the full picture of PM and ammonia emission potential from rural Canada. If agriculture and rural PM emissions were re-defined to include these "other" contributions, such as the transportation sector, the total contribution to $\mathrm{PM}_{2.5}$ in 2017 would equate to $7.49 \times 10^{5}$ tonnes making the contribution of the agriculture and rural sector in Canada significantly larger. It was further noted that the burning of agricultural wastes is not yet included in the APEI reporting system and is therefore not reflected in the emission summary (APEI 2019).

The sources of $\mathrm{PM}_{2.5}$ listed above in Table 4, are determined based on in-house estimates by the ECCC using emission factors and data from reputable sources. Estimates for PM are based off the research of Seedorf (2004), Takai et al. (1998), Van Heyst (2005), and Van Heyst and Roumeliotis (2007). Seedorf (2004) provides emission factors for PM based on the measurement of bioaerosols, while Takai et al. (1998) provides emission rates of respirable and inhalable dust measured through gravimetric analysis of filters. Both studies provided data gathered from inside several housing facilities of different animal species (beef, dairy, swine, poultry) located in Europe. The studies by Van Heyst (2005) and Van Heyst and Roumeliotis (2007) do provide estimates of secondary $\mathrm{PM}_{2.5}$ emissions data, but only for a small sampling of poultry facilities in
Ontario, Canada. PM data used for the General Inventory of animal production are based on Pattey and Qiu Guowang (2012) and Pattey et al. (2015) and are based on primary PM emissions.

Secondary $\mathrm{PM}_{2.5}$ emissions in Canada are not yet clearly specified within the national inventory as emissions are typically calculated based on emission factors which, as outlined above, do not clearly outline the contribution from SIA formation for animal species other than poultry. While $\mathrm{PM}_{2.5}$ data gathered by monitoring stations is not restrictive of SIA, it is important to understand what species of $\mathrm{PM}_{2.5}$ are being measured and what sources they are being emitted from. For example, the formation of SIA, driven by ammonia precursor gas, would indicate an agricultural/rural source of $\mathrm{PM}_{2.5}$. Knowing this would then allow researchers to determine what impact agricultural and rural emissions have on the concentrations measured in urban areas, and then subsequently understand how it is impacting human health. Without knowing the fractionation of $\mathrm{PM}_{2.5}$, a true reflection of the impacts based on source is not well known and mitigation measures may be misallocated.

Ammonia's conversion to SIA is complex and varies based on environmental conditions (season, time of day, and environmental conditions) occurring at and in the vicinity of the source of the ammonia emissions (Roumeliotis et al. 2010). Few works (Aneja et al. 2006;

Table 5. Secondary PM2.5 from ammonia - Referencing data presented in Table 4.

\begin{tabular}{|c|c|c|c|c|c|}
\hline Emission Source & $\begin{array}{l}\text { Reported } \\
\mathrm{PM}_{2.5} \text { (tonnes) }\end{array}$ & $\begin{array}{l}\text { Reported } \\
\text { Ammonia } \\
\text { (tonnes) }\end{array}$ & $\begin{array}{l}7 \% \text { Ammonia to } \\
\text { Secondary } \mathrm{PM}_{2.5} \\
\text { (tonnes) }\end{array}$ & $\begin{array}{l}11 \% \text { Ammonia to } \\
\text { Secondary } \mathrm{PM}_{2.5} \\
\text { (tonnes) }\end{array}$ & $\begin{array}{l}\text { New Estimated } \mathrm{PM}_{2.5} \text { Total } \\
(7 \%-11 \% \text { conversion) } \\
\text { (tonnes) }\end{array}$ \\
\hline \multicolumn{6}{|c|}{ Agriculture and Rural Sources } \\
\hline Animal Production & $2.08 \times 10^{3}$ & $2.86 \times 10^{5}$ & $2.00 \times 10^{4}$ & $3.15 \times 10^{4}$ & $2.21 \times 10^{4}-3.36 \times 10^{4}$ \\
\hline Crop Production & $3.78 \times 10^{5}$ & $1.59 \times 10^{5}$ & $1.12 \times 10^{4}$ & $1.75 \times 10 \mathrm{v}$ & $3.89 \times 10^{5}-3.95 \times 10^{5}$ \\
\hline Fuel Use & 377 & 43 & 3.01 & 4.72 & $380-382$ \\
\hline \multicolumn{6}{|c|}{ Other (Rural) Sources } \\
\hline Dust Unpaved Roads & $3.55 \times 10^{5}$ & - & - & - & - \\
\hline $\begin{array}{l}\text { Off-Road Diesel } \\
\text { Vehicles }\end{array}$ & $1.07 \times 10^{4}$ & 192 & 14 & 21 & $1.07 \times 10^{4}$ \\
\hline $\begin{array}{l}\text { Off-Road Gasoline } \\
\text { Vehicles }\end{array}$ & 3743 & 90 & 6 & 10 & $3749-3753$ \\
\hline Total & $7.49 \times 10^{5}$ & $4.46 \times 10^{5}$ & $3.12 \times 10^{4}$ & $4.91 \times 10^{4}$ & $4.26 \times 10^{5}-4.44 \times 10^{5}$ \\
\hline
\end{tabular}


Behera and Sharma 2010) report the percent conversions of ammonium to $\mathrm{PM}_{2.5}$, due in part to the confounding conditions. Aneja et al. (2006) reported, based on samples collected in rural North Carolina, that $7 \%$ to $11 \%$ of ammonium was converted to $\mathrm{PM}_{2.5}$ due to the neutralization reaction, and Behera and Sharma (2010) stated that these reactions could account for upwards of $30 \%$ of the mass of $\mathrm{PM}_{2.5}$. This information, although limited, indicates that precursor gases, such as ammonia when considering the agricultural sector, are responsible for a portion of the measured $\mathrm{PM}_{2.5}$ quantities. For demonstration purposes, the SIA PM PM. $_{2 .}$ burden that could be attributed to agriculture is conservatively estimated in Table 5 below based on the reported conversion percentages from Aneja et al. (2006) and the amount of ammonia reported in Canada for 2017 (APEI 2019). The conversion presented here is based solely on the findings from Aneja et al. (2006) who found of the total $\mathrm{PM}_{2.5}$ generated in a poultry house, $7 \%$ to $11 \%$ of it was due to SIA formation.

Based on the masses estimated above in Table 5, ammonia would account for approximately $3.12 \times 10^{4}$ to $4.91 \times 10^{4}$ tonnes of the total $\mathrm{PM}_{2.5}$ burden annually in Canada from agriculture and rurally sources. While these contributions are variable, the reality is that while ammonia emissions from agriculture and rural sources in Canada continues to increase (APEI 2019), it will also continue to fuel the formation of SIA's, contributing to the overall $\mathrm{PM}_{2.5}$ burden and continue to exacerbate the already increasing breadth of health impacts suffered nationally (and globally) due to fine particulate matter.

\section{Health impacts from agricultural practices}

Globally, air pollution is a significant health risk for both humans and animals (Prüss-Ustüm et al. 2016; WHO 2013). However, the impact that PM generated by agricultural practices has on human health is one that is being explored more recently. As there is a significant source of particulate matter emitted from Canadian agriculture, a study by Khan (2015) looked at the occurrence of respiratory disease leading to hospital admissions in the Prairie Provinces (Alberta, Saskatchewan, and Manitoba) due to $\mathrm{PM}_{2.5}$. The statistical modelling performed by Khan (2015) outlined that there is a correlation with hospital admissions for respiratory disease and $\mathrm{PM}_{2.5}$ emissions during 2009 and 2010.

Similar studies have been conducted in the United States using long term health cohort information. Weichenthal et al. (2014) looked at the health information presented in the US Agriculture Health Study Cohort. The 83,378 individuals enrolled in this cohort were farmers, commercial pesticide applicators, and their families from Iowa and North Carolina. This study is unique in that it focused strictly on individuals working in the agricultural sector but, like the studies discussed above, the results were similar. Specifically, a positive correlation between cardiovascular deaths and men was found as compared to their female counterparts only because they tended to work significantly longer hours outdoors. While not a Canadian specific study, agricultural practices and population demographics are similar between Canada and the United States.

\section{CONCLUSIONS}

To date, the major focus of $\mathrm{PM}_{2.5}$ research in Canada has been conducted using data from urban dwelling populations and $\mathrm{PM}_{2.5}$ data with few studies looking into the sources and health impacts occurring in rural/agricultural areas. The formation of SIA's, a known contributor to $\mathrm{PM}_{2.5}$, is fueled in part by ammonia emissions that are linked to animal and crop production, and a contributor to the overall $\mathrm{PM}_{2.5}$ burden. However, a current lack of understanding with respect to the source apportionment and fractionation of rural $\mathrm{PM}_{2.5}$, restricts the understanding of the full impact of this pollutant on human health.

Across the globe, health impacts from air pollution and particulate matter are felt in a variety of ways. By 2050 , premature death caused by air pollution is expected to double from current values (Lelieveld et al. 2015). Due to the lack of monitoring programs in place (WHO 2013), specifically in rural areas, it is still difficult to properly quantify emissions of fine particulates thus making it difficult to predict health impacts (Lelieveld et al. 2015) or long-term trends in data (Stieb et al. 2015). To further complicate this, the speciation between primary and secondary $\mathrm{PM}_{2.5}$, has yet to be directly quantified in Canadian reporting systems. Given the surmounting longterm health impacts and increasing deaths linked to $\mathrm{PM}_{2.5}$ and the significant, yet less understood quantification of rural based $\mathrm{PM}_{2.5}$, gaining a deeper understanding of the impact of rural emission sources should be explored more holistically.

Discovered throughout this paper was that current $\mathrm{PM}_{2.5}$ monitoring taking place in Canadian rural areas is significantly less as compared to urban. What is less understood is the fractionation of $\mathrm{PM}_{2.5}$ that is directly attributed to agricultural production in these rural areas. Current $\mathrm{PM}_{2.5}$ data is based on in-house estimates and emission factors that do not distinguish the contribution of secondary $\mathrm{PM}_{2.5}$ to the overall $\mathrm{PM}_{2.5}$ quantity. Knowing this will help build our understanding of the contribution that agricultural $\mathrm{PM}_{2.5}$ has on the overall $\mathrm{PM}$ burden and, ultimately, the impact on human health.

\section{ACKNOWLEDGMENT}

The authors would like to acknowledge the supporters of this research: Ontario Ministry of Agriculture, Food and Rural Affairs (OMAFRA), the Canadian Poultry Research Council (CPRC), and the University of Guelph's School of Engineering.

\section{REFERENCES}

Agriculture and Agri-Food Canada (AAFC). 2016. Particulate matter indicator (PMI). Agriculture and Agri-Food Canada. http://www.agr.gc.ca/eng/scienceand-innovation/agricultural-practices/climate-changeand-agriculture/particulate-matterindicator/?id=1462392213883. (2017/03/10).

Agriculture and Agri-Food Canada (AAFC). 2017. An Overview of the Canadian Agriculture and Agri-Food System 2017. http://www.agr.gc.ca/eng/aboutus/publications/economic-publications/an-overviewof-the-canadian-agriculture-and-agri-food-system2017/?id=1510326669269. $(2019 / 01 / 15)$. 
Agriculture and Agri-Food Canada (AAFC). 2018. Continued Strength and Growth Expected for Canada's Agricultural Sector. Agriculture and Agri-Food Canada News Release March 27, 2018. https://www.canada .ca/en/agriculture-agri-food/news/2018/03/continuedstrength-and-growth-expected-for-canadasagricultural-sector.html. (2019/01/15).

Air Pollutant Emission Inventory (APEI). 2019. Canada's air pollutant emissions inventory report. Cat. No.: En81-30E-PDF. https://ec.gc.ca/pollution/default.asp? lang=En\&n=E96450C4-1. (2019/04/14).

Aneja, V., Wang, B., and Tong, D.Q. 2006. Characterization of major chemical components of fine particulate matter in north carolina. Journal of Air and Waste Management Association 56: 1099-1107. https://doi.org/10.1080/10473289.2006.10464529

Behera, S.N. and Sharma, M. 2010. Investigating the potential role of ammonia in ion chemistry of fine particulate matter formation for an urban environment. Science of the Total Environment 408: 3569-3575. https://doi.org/10.1016/j.scitotenv.2010.04.017

Brauer, M., Lencar, C., Tamburic, L., Koehoorn, M., Demers, P. and Karr, C. 2008. A cohort study of traffic related air pollution impacts on birth outcomes. Environmental Health Perspectives 116(5): 680-686. https://doi.org/10.1289/ehp.10952

Brook, R.D., Cakmak, s., Turner, M.C., Brook, J.R., Crouse, D.L., Peters, P.A., van Donkelaar, A., Villeneuve, P.J., Brion, O., Jerrett, M., Martin, R.V., Rajagopalan, S., Goldberg, M.S., Pope, C.A. and Burnett, R.T. 2013. Long-term fine particulate matter exposure and mortality from diabetes in Canada. Diabetes Care 36(10):3313-3320.

https://doi.org/10.2337/dc12-2189

Brook, J., Dann T., Galarneau E., Herod D., Charland J. 2014. The state of air quality in Canada: national patterns. Air Quality Management. In: Taylor E., McMillan A. (eds); pp. 43-67.

https://doi.org/10.1007/978-94-007-7557-2_3

Bowe, B., Xie, Y., Li, T., Yan, Y., Xian, H., and Al-Aly, Z. 2017. Particulate matter air pollution and the risk of incident CKD and progression to ESRD. Journal of the American Society of Nephrology. (Published online before print) DOI: 10.1681/ASN.2017030253. https://doi.org/10.1681/ASN.2017030253

Chen, H., Kwong, J.C., Copes, R., Hystad, P., van Donkelaar, A., Ru, K.R., Brook, J.R., Goldberg, M.S., Martin, R.V., Murray, B.J., Wilton, A.S., Kopp, A. and Burnett, R.T. 2017. Exposure to ambient air pollution and the incidence of dementia: a population-based study. Environmental International 108:271-277. https://doi.org/10.1016/j.envint.2017.08.020

Chen, H., Burnett, R.T., Kwong, J.C., Villeneuve, P.J., Goldberg, M.S., Brook, R.D., van Donkelaar, A., Jerrett, M., Martive, R.V., Kopp, A., Brook, J.R., and Copes, R. 2014. Spatial Association between ambient fine particulate matter and incident hypertension. Circulation 129(5): 562-569.

https://doi.org/10.1161/circulationaha.113.003532
Chen, H., Burnett, R.T., Kwong, J.C., Villeneuve, P.J., Goldberg, M.S., Brook, R.D., van Donkelaar, A., Jerrett, M., Martin, R.V., Brook, J.R., and Copes, R. 2013. Risk of incident diabetes in relation to long-term exposure to fine particulate matter in Ontario, Canada. Environmental Health Perspectives 121(7): 804-810. https://doi.org/10.1289/ehp.1205958

Chen, Y., Yang, Q.Y., Krewski, D., Shi, Y., Burnett, R.T., and McGrail, K. 2004. Influence of relatively low level of particulate air pollution on hospitalization for COPD in elderly people. Inhalation Toxicology 16(1): 21-25. https://doi.org/10.1080/08958370490258129

CCOHS (Canadian Centre for Occupational and Health Safety). 2018. How Do Particulates Enter the Respiratory System.

http://www.ccohs.ca/oshanswers/chemicals/ how_do.html. (2013/01/30).

CCME (Canadian Council of Ministers of the Environment). 2014. Canada-wide standards for particulate matter and ozone: 2012 final report. Winnipeg, Manitoba: Canadian Council of Ministers of the Environment.

Crouse, D.L., Peters, P.A., van Donkelaar, A., Goldberg, M.S., Villeneuve, P.J., Brion, O., Khan, S., Atari, D.O., Jerrett, M., Pope III, C.A., Brauer, M., Brook, J.R., Martin, R.V., Stieb, D., and Burnett, R.T. 2012. Risk of non-accidental and cardiovascular mortality in relation to long-term exposure to low concentrations of fine particulate matter: a Canadian national-level cohort study. Environmental Health Perspectives 120(5): 708714. https://doi.org/10.1289/ehp.1104049

Elliott, C.T. and Copes, R. 2011. Burden of mortality due to ambient fine particulate air pollution (PM2.5) in interior and northern BC. Canadian Journal of Public Health 102(5): 390-393.

Environment and Climate Change Canada (ECCC). 2013. Canadian ambient air quality standards. $\mathrm{http}: / /$ www.ec.gc.ca/default.asp?lang=En\&n=56D404 3B-1\&news=A4B2C28A-2DFB-4BF4-8777ADF29B4360BD. (2017/03/20).

Environment and Climate Change Canada (ECCC). 2014. Average ambient fine particulate matter concentrations at monitoring stations. http://maps-cartes.ec.gc.ca/ indicators-indicateurs/TableView.aspx?ID $=17 \&$ lang $=$ en. $(2017 / 10 / 27)$.

Environment and Climate Change Canada (ECCC). 2016. Air pollutant emission inventory (APEI) report: 19902015 air pollutant emission inventory report. http://www.ec.gc.ca/pollution/default.asp?lang=En\&n $=$ A17452DA-1\&offset=2\&toc=show. (2017/03/09).

Environment and Climate Change Canada (ECCC). 2018. 1990-2016 Air pollutant emission inventory (APEI) report. Environment and Climate Change Canada. Catalogue No.: En81-26E-PDF. ISSN: 2369-940X.

Environment and Climate Change Canada (ECCC). 2017. Air pollutant emissions: Canadian environmental sustainability indicators. https://www.ec.gc.ca/ indicateurs-indicators/default.asp?lang=en\&n= 52F0AE93-1. (2017/10/16). 
Erickson, A.C., Ostry, A., Chan, L.H.M., and Arbour, L. 2016. The reduction of birth weight by fine particulate matter and its modification by maternal and neighbourhood-level factors: a multilevel analysis in British Columbia, Canada. Environmental Health. 15(51). https://doi.org/10.1186/s12940-016-0133-0

European Commission. 2017. Environment: air quality standards, 2017.

http://ec.europa.eu/environment/air/quality/standards. htm. $(2017 / 10 / 12)$.

Evans, J., Chen, Y., Camp, P.G., Bowie, D.M, and McRae, L. 2014. Estimating the prevalence of COPD in Canada: reported diagnosis versus measured airflow obstruction. Statistics Canada Catalogue no. 82-003-X Health Reports. 25(2): 3-11.

Gan, W.Q., Koehoorn, M., Davies, H.W., Demers, P.A., Tamburic, L., and Brauer, M. 2011. Long-term exposure to traffic-related air pollution and the risk of coronary heart disease hospitalization and mortality. Environmental Health Perspectives 119(4): 501-507. https://doi.org/10.1289/ehp.1002511

Goldberg, M.S., Burnett, R.T., Yale, J.F.O., Valois, M.F., and Brook, J.R. 2006. Associations between ambient air pollution and daily mortality among persons with diabetes and cardiovascular disease. Environmental Research 100(2):255-267.

https://doi.org/10.1016/j.envres.2005.04.007

Government of Canada: Air pollutants overview. 2017. https://www.canada.ca/en/environment-climatechange/services/air-pollution/pollutants/ overview.html. (2017/10/28).

Jerrett, M., Burnett, R.T., Brook, J., Kanaroglou, P., Giovis, C., Finkelstein, N., and Hutchison, B. 2004. Do socioeconomic characteristics modify the short-term association between air pollution and mortality? Evidence from a zonal time series in Hamilton, Canada. Journal of Epidemiology and Community Health 58(1):31-40. https://doi.org/10.1136/jech.58.1.31

Khan, S.A. 2015. Atmospheric concentration of fine particulate matter and its impact on daily hospital admission for respiratory disease in the prairies of Canada. International Journal of Environmental Studies. 72(4):650-666. https://doi.org/10.1080/00207233.2015.1054141

Koenig, J.Q. 2000. Health Effects of Ambient Air Pollution; How safe is the air we breathe? Boston, Mass. USA: Kluwer Academic Publishers. https://doi.org/10.1007/978-1-4615-4569-9

Lavigne, E., Belair, M.A., Do, M.T., Stieb, D.M., Hystad, P., van Donkelaar, A., Martin, R.V., Crouse, D.L., Crighton, E., Chen, H., Brook, J.R., Burnett, R.T., Weichenthal, S., Villeneuve, P.J., To, T., Cakmak, S., Johnson, M., Yasseen, A.S., Johnson, K.C., Ofner, M., Xie, L., and Walker, M. 2017. Maternal exposure to ambient air pollution and risk of early childhood cancers: A population-based study in Ontario, Canada. Environment International 100:139-147.

https://doi.org/10.1016/j.envint.2017.01.004
Lelieveld, J., Evans, J.S., Fnais, M., Giannadaki, D., and Pozzer, A. 2015. The contribution of outdoor air pollution sources to premature mortality on a global scale. Nature 535(2015): 367-384.

https://doi.org/10.1038/nature15371

Ministry of the Environment and Climate Change (MOECC). 2017. Air contaminants benchmark list: standards, guidelines and screening levels for assessing point of impingement concentrations of air contaminants. https://www.ontario.ca/page/aircontaminants-benchmarks-list-standards-guidelinesand-screening-levels-assessing-point (2017/04/02).

Pattey, E., and Qiu, Guowang.Q. 2012. Trends in primary particulate matter emissions form Canadian agriculture. Journal of the Air and Waste Management Association. 62(7):737-747. https://doi.org/10.1080/10962247.2012.672058

Pattey, E., and Qiu Guowang, Q. 2015. Primary Particulate matter emissions and trends from Canadian agriculture. 23rd International Conference on Modelling, Monitoring and Management of Air Pollution. Valencia, Spain. https://doi.org/10.2495/AIR150121

Pearson, J.F., Bachireddy, C., Shyamprasad, S., Goldfine, A.B., and Brownstein, J.S. 2010. Association between fine particulate matter and diabetes prevalence in the US. Diabetes Care 33(10): 2196-2201. https://doi.org/10.2337/dc10-0698

Pinault, L., Tjepkema, M., Crouse, D.L., Weichenthal, S., van Donkelaar, A., Martin, R.V., Brauer, M., Chen, H., and Burnett, R.T. 2016. Risk estimates of mortality attributed to low concentrations of ambient fine particulate matter in the Canadian community health survey cohort. Environmental Health 15:18. 1 - 15. https://doi.org/10.1186/s12940-016-0111-6

Pope III, C.A., Burnett, R.T., Thurston, G.D., Thun, M.J., Calle, E.E., Krewski, D. and Godleski, J.J. 2004. Cardiovascular mortality and long-term exposure to particulate air pollution, epidemiological evidence of general pathophysiological pathways of disease. Journal of the American Heart Association 109: 71-77. https://doi.org/10.1161/01.CIR.0000108927.80044.7F

Pope III, C.A., and Dockery, D.W. 2006. Health effects of fine particulate air pollution: lines that connect. Journal of Air and Waste Management Associate 56:709-742. https://doi.org/10.1080/10473289.2006.10464485

Prüss-Ustüm, A., Wolf, J., Corvalán, C., Bos, R., and Neira, M. 2016. Preventing disease through healthy environments: a global assessment of the burden of disease from environmental risks. Geneva, Switzerland. WHO Press.

Requia, W.J., Adams, M.D., Koutrakis, P. 2017. Association of PM2.5 with diabetes, asthma, and high blood pressure incidence in Canada: a spatiotemporal analysis of the impacts of the energy generation and fuel sales. Science of the Total Environment 584:10771083. https://doi.org/10.1016/j.scitotenv.2017.01.166

Romley, J.A., Hackbarth, A. and Goldman, D.P. 2012. The impact of air quality on hospital spending. RAND Health Quarterly 2(3):6. 
Roumeliotis, T.S., Dixon, B.J., and Van Heyst, B.J. 2010. Characterization of gaseous pollutant and particulate matter emission rates from a commercial broiler operation part I: observed trends in emissions. Atmospheric Environment 44(31):3770-3777. https://doi.org/10.1016/j.atmosenv.2010.06.052

Seedorf, J. 2004. An emission inventory of livestock-related bioaerosols for Lower Saxony Germany. Atmospheric Environment 38:6565-6581.

https://doi.org/10.1016/j.atmosenv.2004.08.023

Silva, R.A., Adelman, Z., Fry, M.M., and West, J.J. 2016. The impact of individual anthropogenic emissions sectors on the global health burden of human mortality due to ambient air pollution. Environmental Health Perspectives 124(11):1776-1784.

https://doi.org/10.1289/EHP177

Smith, R. and McDougal, K. 2017. Costs of pollution in Canada: measuring the impacts on families, businesses and governments. International Institute for Sustainable Development.

http://www.iisd.org/library/cost-pollution-canada $(2017 / 09 / 03)$.

Statistics Canada. 2011. Population, urban and rural, by province and territory. http://www.statcan.gc.ca/tablestableaux/sum-som/101/cst01/demo62a-eng.htm. (2017/10/26).

Statistic Canada. 2016a. Census of agriculture. https://www.statcan.gc.ca/dailyquotidien/170510/dq170510a-eng.htm. (2017/06/10).

Statistics Canada. 2016b. Census profile. Statistics Canada Catalogue no. 98-316-X2016001. http://www12.statcan.gc.ca/censusrecensement/2016/dp-pd/prof/index.cfm?Lang=E. (2017/10/26).

Statistics Canada. 2017. 2016 Census of Agriculture. Component of Statistics Canada catalogue no. 11-011$\mathrm{X}$.

Statistics Canada. 2018. Population and Dwelling Count Highlight Tables, $2016 \quad$ Census. https://www12.statcan.gc.ca/censusrecensement/2016/dp-pd/hlt-fst/pd$\mathrm{pl} /$ Table.cfm? Lang $=$ Eng $\& \mathrm{~T}=101 \& \mathrm{~S}=50 \& \mathrm{O}=\mathrm{A}$. (2019/01/20).

Stieb, D.M., Judek, S., van Donkelaar, A., Martin, R.V., Brand, K., Shin, H.H., Burnett, R.T., and SmithDoiron, M.H. 2015. Estimated public health impacts of changes in concentrations of fine particle air pollution in Canada, 2000 to 2011. Canadian Journal of Public Health 106(6): E362-E368.

https://doi.org/10.17269/CJPH.106.4983

Szyszkowicz, M. and Kousha, T. 2014. Emergency department visits for asthma in relation to the Air Quality Health Index: A case-crossover study in Windsor, Ontario. Canadian Journal of Public Health. 105(5):e336-e341.

https://doi.org/10.17269/cjph.105.4539
Takai, H., Pedersen, S., Johnsen, J.O., Metz, J.H.M., Groot Koerkamp, P.W.G., Uenk, G.H., Phillips, V.R., Holden, M.R., Sneath, R.W., Short, J.L., White, R.P., Hartung, J., Seedorf, J., Schröder, M., Linkert, K.H., Wathes, C.M. 1998. Concentrations and emissions of airborne dust in livestock buildings in Northern Europe. Journal of Agriculture Engineering Resources 70(1):59-77. https://doi.org/10.1006/jaer.1997.0280

To, T., Zhu, J.Q., Villeneuve, P.J., Simatovic, J., Feldman, L., Gao, C.W., Williams, D., Chen, H., Weichenthal, S., Wall, C., and Miller, A.B. 2015a. Chronic disease prevalence in women and air pollution - A 30-year longitudinal cohort study. Environment International 80:26-32. https://doi.org/10.1016/j.envint.2015.03.017

To, T., Feldman, L., Simatovic, J., Gershon, A.S., Dell, S., Su, J.D., Foty, R., and Licskai, C. 2015b. Health risk of air pollution on people living with major chronic diseases: a Canadian population-based study. BMJ Open 5(9). https://doi.org/10.1136/bmjopen-2015009075

Tetreault, L.F., Doucet, M., Gamache, P., Fournier, M., Brand, A., Kosatsky, T., and Smargiassi, A. 2016. Childhood exposure to ambient air pollutants and the onset of asthma: an administrative cohort study in Quebec. Environmental Health Perspectives 124(8):1276-1282. https://doi.org/10.1289/ehp.1509838

US EPA (United States Environmental Protection Agency). 2016a. Particulate matter (PM) basics. https://www.epa.gov/pm-pollution/particulate-matterpm-basics\#PM. (2018/04/18).

US EPA (United States Environmental Protection Agency). 2016b. Criteria air pollutants: NAAQS (national ambient air quality standards) table. https://www.epa.gov/criteria-air-pollutants/naaqstable. $(2016 / 02 / 23)$.

Valavanidis, A., Fiotakis, K., and Vlachogianni, T. 2008. Airborne Particulate Matter and Human Health: Toxicological Assessment and Importance of Size and Composition of Particles for Oxidative Damage and Carcinogenic Mechanism. Journal of Environmental Science and Health Part C 26:339-362. https://doi.org/10.1080/10590500802494538

Van Heyst, B.J. 2005. Final report: Evaluation of emission factors for the improvement of the estimation methodology for particulate matter from agricultural poultry industry. University of Guelph. Report No. K2361-04-0016.

Van Heyst, B.J. and Roumeliotis, T.S. 2007. Size fractionated particle matter emissions from a broiler house in southern Ontario, Canada. Science of the Total Environment 383:174-182. https://doi.org/10.1016/j.scitotenv.2007.05.003

Villeneuve, P.J., Weichenthal, S.A., Crouse, D., Miller, A.B., To, T., Martin, R.V., van Donkelaar, A., Wall, C., and Burnett, R.T. 2015. Long-term exposure to fine 
particulate matter air pollution and mortality among Canadian women. Epidemiology 26(4):536-545. https://doi.org/10.1097/EDE.0000000000000294

Villeneuve, P.J., Burnett, R.T., Shi, Y.L., Krewski, D., Goldberg, M.S., Hertzman, C., Chen, Y., and Brook, J. 2003. A time-series study of air pollution, socioeconomic status, and mortality in Vancouver, Canada. Journal of Exposure Analysis and Environmental Epidemiology 13(6):427-435. https://doi.org/10.1038/sj.jea.7500292

Weichenthal, S.A., Villeneuve, P.J., Burnett, R.T., van Donkelaar, A., Martin, R.V., Jones, R.R., DellaValle, C.T., Sandler, D.P., Ward, M.H., and Hoppin, J.A. 2014. Long-term exposure to fine particulate matter: association with nonaccidental and cardiovascular mortality in the agricultural health study cohort. Environmental Health Perspectives 122(6):609-615. https://doi.org/10.1289/ehp.1307277

Weichenthal, S.A., Lavigne, E., Evans, G.J., Godri Pollitt, K.J., and Burnett, R.T. 2016. Fine particulate matter and emergency room visits for respiratory illness effect modification by oxidative potential. American Journal of Respiratory and Critical Care Medicine 194(5):577-586. https://doi.org/10.1164/rccm.20151224340C
World Health Organization (WHO). 2006. WHO air quality guidelines for particulate matter, ozone, nitrogen dioxide and sulfur dioxide: global update 2005. Summary of risk assessment. Geneva, Switzerland: WHO Press.

World Health Organization (WHO). 2013. Health effects of particulate matter policy implications for countries in eastern Europe, Caucasus and central Asia. World Health Organization, Regional Office for Europe, Copenhagen, Denmark.

World Health Organization (WHO). 2015. Economic cost of the health impact of air pollution in Europe, clean air, health and wealth. WHO Regional Office for Europe, Copenhagen, Denmark.

World Health Organization (WHO). 2016a. Ambient (outdoor) air quality and health: fact sheet. http:/www.who.int/mediacentre/factsheets/fs313/en/. (2017/03/20).

World Health Organization (WHO). 2016b. WHO global urban ambient air pollution database - (update 2016). Public health, environmental and social determinants of health (PHE). http://www.who.int/phe/health_topics/outdoorair/data bases/cities/en/. (2017/06/20). 